\section{Hemoglobin disorders in Europe: a systematic effort of identifying and addressing unmet needs and challenges by the Thalassemia International Federation}

\author{
Michael Angastiniotis, ${ }^{1}$ Lily Cannon, ${ }^{1}$ \\ Eleni Antoniou, ${ }^{1}$ Angelo Loris Brunetta, \\ George Constantinou, ${ }^{1}$ Eva Maria Knoll \\ Knoll, ${ }^{2}$ Dimitris Loukopoulos, ${ }^{3}$ Anton \\ Skafi, ${ }^{1}$ Androulla Eleftheriou ${ }^{1}$
}

1Thalassaemia International Federation, Nicosia, Cyprus; ${ }^{2}$ Institute for Social Anthropology, Austrian Academy of Sciences, Vienna, Austria; ${ }^{3}$ National and Kapodistrian, University of Athens Medical School and Biomedical Research Foundation of the Academy of Athens, Athens, Greece

\begin{abstract}
Hemoglobin disorders (thalassemia and sickle cell disease) are a group of hereditary anemias that today occur across the world. The recent population movement has led to a steady increase of carriers and patients in all countries of the European Union. Requiring complex monitoring and treatment and, as a consequence, well-organized and nationally coordinated, supported and funded services, these lifelong conditions are now visible to healthcare services in the EU. The purpose of this study is to provide an overview of the current situation pertaining to these disorders, as perceived by the patient/parent community that the Thalassemia International Federation (TIF) represents. The aim is to establish a comprehensive understanding of the situation and unmet needs faced by migrants with thalassemia. The implementation of activities by TIF in 2018-2020 to identify and address these challenges, paves the way to increased awareness, education and policy changes building on international expertise and knowledge that will enable the provision of state-of-art clinical management services thus guaranteeing an improved quality of life. A bird's eye view of the prevalence of these disorders is presented contributing to the further understanding of challenges met by both patients and healthcare professionals in the receipt and provision of quality healthcare respectively.
\end{abstract}

\section{Introduction}

Hemoglobin disorders are a group of hereditary anemias caused by genetic mutations affecting the production of the globin chains of the hemoglobin molecule. Their prevalence seems to be related to past or present prevalence of Plasmodium falciparum malaria across the globe, since it appears that healthy carriers have a selective advantage over non-carriers as far as survival to malarial infection is concerned. There is a geographical coincidence of haemoglobinopathy prevalence, with those parts of Europe where malaria was rampant in the past. ${ }^{1}$ Cyprus is a primary example of this phenomenon, since until its eradication in 1948, malaria was a major public health problem; the beta thalassemia carrier rate was recorded to be $15-18 \% .^{2}$ Lowland regions of Greece, Italy and Turkey were similarly affected.

\section{Geographical distribution in Europe}

High prevalence globally, for both thalassemia and sickle cell disease (SCD), appears to range from the Mediterranean basin across Africa and the Middle East to the Far East reaching the Pacific coast. In the European setting, the countries in which the indigenous population is most affected are the South of France, Italy, Greece, Albania, Turkey and the Mediterranean islands. Some countries to the north of these, such as the Balkans are less affected as is the Iberian Peninsula. Southern Russia and the Caucasus have a variable prevalence, with the exception of Azerbaijan which has a high prevalence. North of these areas are most European countries where beta and alpha thalassemia are extremely uncommon (with around $0.1-0.2 \%$ of the population being heterozygotes), while sickle cell genes and other variants are almost unknown in the indigenous populations (Figure 1).

Historical population movements in the early and mid-20th century from high prevalence countries have introduced these disorders to the countries of Western Europe (e.g. UK and France) and the Americas (e.g. USA, Canada and Brazil). Furthermore, more recent population movements to Europe, of different causality, voluntary or forced, have changed the European landscape in the area of hemoglobin disorders, and have led to a steady increase of carriers and patients in all countries of the European Union, including formerly low prevalence countries such as Scandinavian countries (viz. Denmark, Sweden) and Central European countries (v. Slovakia, Czech Republic). ${ }^{3,4}$ A migration flow from the east has followed a transit
Correspondence: Androulla Eleftheriou, Executive Director, Thalassemia International Federation; 31, Ifigenias Street, 2007 Strovolos, Nicosia, Cyprus.

Tel.: +35.722319129.

E-mail: thalassaemia@cytanet.com.cy

Key words: Thalassemia; sickle cell disease; hemoglobin disorders; prevalence; migration; Europe.

Conflict of interests: the authors declare no potential conflict of interests.

Novelty statement: An updated bird's eye view of the prevalence of hemoglobin disorders is presented following the recent migration flow to Europe in 2015. Understanding the distribution of carriers and patients across Europe, contributes to the further understanding of challenges met by both patients and healthcare professionals in the receipt and provision of quality healthcare respectively.

Received for publication: 9 April 2021.

Accepted for publication: 10 April 2021.

This work is licensed under a Creative Commons Attribution 4.0 License (by-nc 4.0)

${ }^{\circ}$ Copyright: the Author(s), 2021

Licensee PAGEPress, Italy

Thalassemia Reports 2021; 11:9803

doi:10.4081/thal.2021.9803

route through Turkey, Greece and the Balkans aiming to reach the countries of Western and Northern Europe (mainly France, Germany and Sweden). From Africa, the origin of most sickle cell carriers, increasing numbers are entering the European continent mainly across the Mediterranean to Italy and Spain. Some among of the persons originating from high prevalence countries of the Middle East, South East Asia and sub-Saharan Africa are likely to be healthy carriers of these disorders or indeed patients. Likewise, persons from Afghanistan, Iraq, Syria, Thailand and Turkey, entering Europe from the Eastern borders of Greece and the Balkans might be carriers of thalassemia or $\mathrm{HbE}$ genes. In Germany, only about 1000-1500 sickle cell patients were recorded in 2014, while in 2016 a neonatal screening study revealed that 1 in 2385 newborns are SCD carriers, probably of Sub-Saharan ancestry. 5,6 The documented number of people settling in Europe until 2015 from high prevalence areas and the subsequent estimated number of carriers based on prevalence rates in their countries of origin is demonstrated in Table $1 .^{8-14}$ In the absence of an internationally accepted definition of migrant, in this publication the term will be used to define any individual who lives outside their country 
of origin for whatever reason either voluntary or forced (e.g. conflict, poverty, political unrest, natural disasters, etc. .). ${ }^{5,6}$

Medical progress now allows for the survival of haemoglobinopathy patients who would have passed away in early childhood until a few decades ago. The increasing numbers of patients together with intensified population migrations from high prevalence countries today make hemoglobin disorders 'visible' to the health services of countries which previously regarded them as extremely rare, having brought new challenges to European health services. ${ }^{5}$ Persons born outside Europe are generally increasing in Europe, but in the context of hemoglobin disorders, it is those migrants that have arrived more recently (after 2012) from high prevalence countries, that are the focus of this study.

Figure 2 represents the number of migrants from high prevalence countries up to 2015 . These estimates concern relatively recent migrations, while other second and third generation migrants are not counted. Since then and up to the end of 2019, another 855,000 have arrived, mainly from high prevalence locations (IOM data). ${ }^{7}$ In addition, unregistered/undocumented illegal entries are estimated to be high, especially from sub-Saharan Africa where the $\mathrm{HbS}$ gene is present in high prevalence. Frontex, the European Union frontier police ${ }^{15}$ estimate that from 2009 to mid-2020, 317,000 such migrants were detected from SubSaharan African countries and another 102,000 from the Maghreb countries and Libya. It is possible that many others may not have been detected. Therefore, it is speculated that as many as half a million people from high prevalence of sickle cell carriers may have entered Europe, with Spain, Italy, France, Germany and the UK being the main recipients. This means that there are around 20 million settlers in European countries of low prevalence for hemoglobin disorders who may have abnormal hemoglobin genes (with the exception of Italy which has both indigenous and migrant high risk populations). This is around $5 \%$ of the total population of the most affected countries.

The increasing size of this public health problem with considerable socio-economic repercussions in Europe is demonstrated by these estimations. Registries, health records and other databases are essential tools for gathering information, which help to define the epidemiology, clinical outcomes and the natural history of these rare conditions, which have been on the rise in much of Northern and Western Europe for quite some time now but the migration crises playing out since 2015 has made these dis- orders more visible as numbers keep rising. Information from such healthcare tools will help to improve the much needed quality of multidisciplinary care and to plan services, as well as to assist in research initiatives including clinical trials. Thus, the development of an EU-wide comprehensive disease-specific Registry is pivotal for monitoring not only the spread of hemoglobin disorders in each country but as a health planning tool that informs national policy for the development of targeted specialized care services and allocation of appropriate financial and human resources (Farmakis $D$, Angastiniotis $M$, Eleftheriou $A$. Thalassemia registries - $A$ call for action: $A$ report of the Thalassemia International Federation; 2020 - undergoing peer review). ${ }^{16}$

\section{Services for hemoglobin disorders}

These lifelong conditions require com-

\section{$\beta$-Thalassaemia Carrier Rate in the Indigenous Population (EURO)}

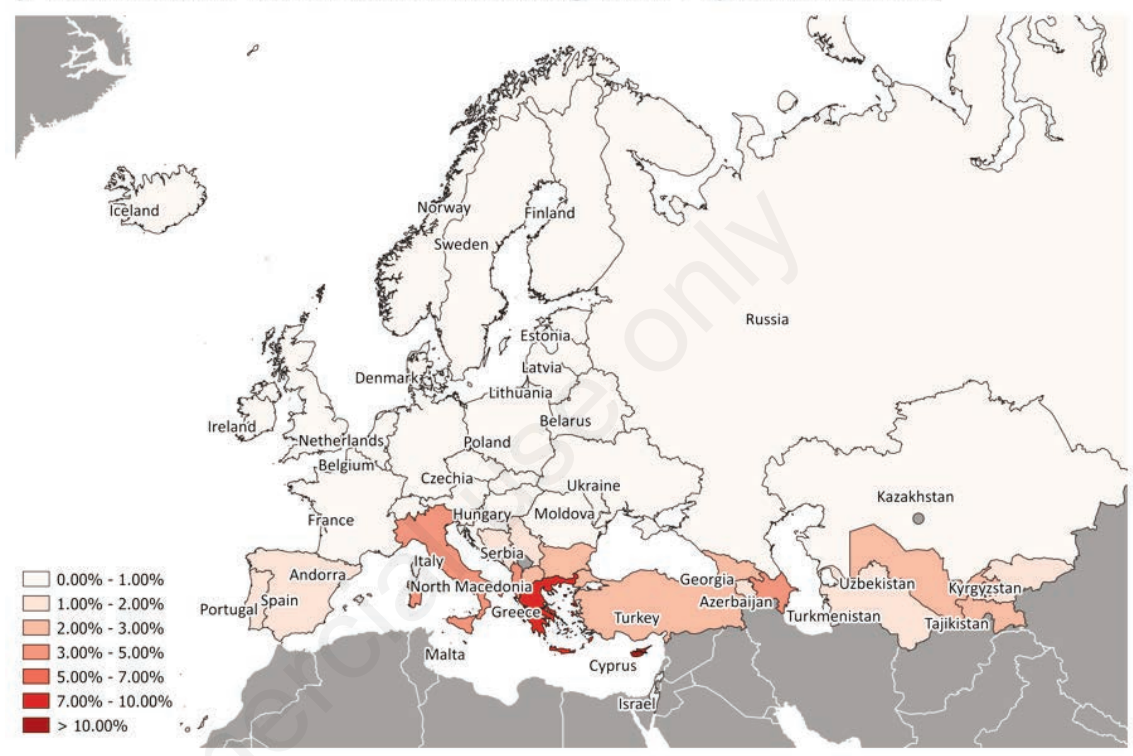

Figure 1. $\beta$-thalassemia carrier rates in the indigenous population of the WHO European Region (2020).

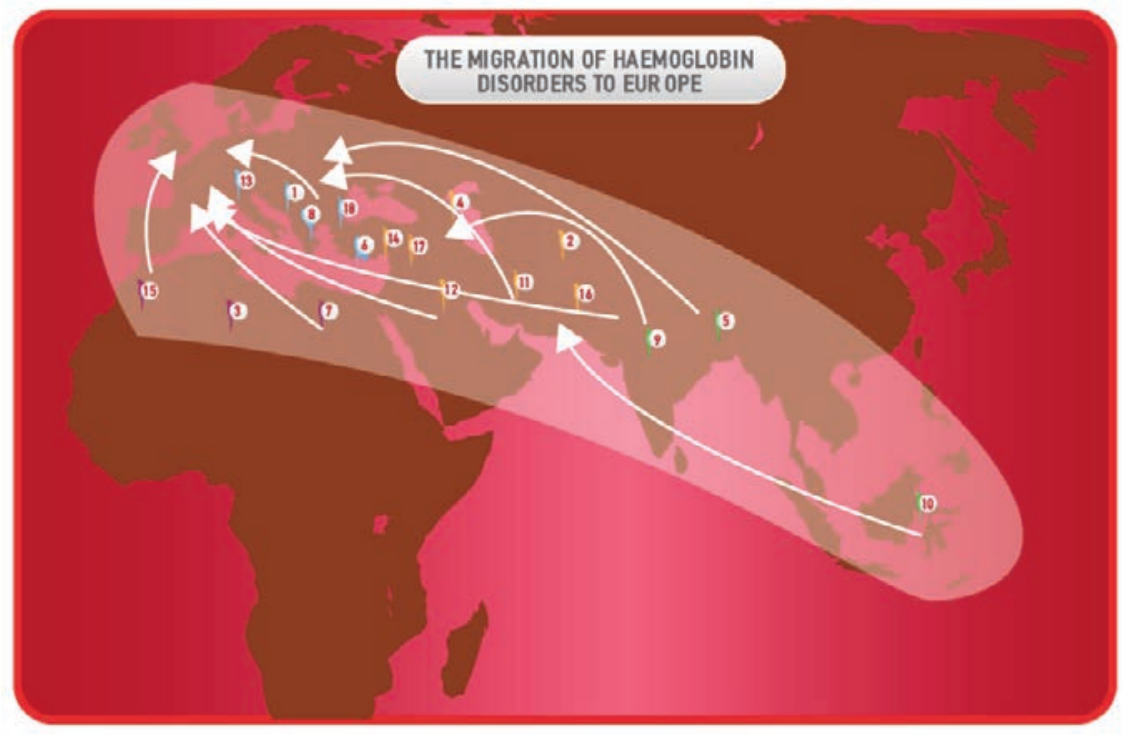

Figure 2. Map showing migration flows into Europe. 
plex monitoring and treatment and, as a consequence, well-organized and nationally coordinated, supported and funded services. These services include the need for regular blood transfusions and iron chelation supported by multi-disciplinary medical collaborations in expert centres ${ }^{17}$ as described in the International Guidelines for Clinical Management of Thalassaemia. ${ }^{18}$ Such organized multidimensional care has been demonstrated to have converted lethal childhood disorders to chronic conditions of adult life, ${ }^{19}$ allowing patients to achieve a near normal life. Scattered minority groups in an environment in which these are rare conditions, may not have access to the expert care that they need. Not being optimally treated will result in poor quality of life, more complications and even more expert and expensive clinical management. In the north and western European settings, such services are available in academic and other reference centers. The European Commission, in its rare disease policy and according to the Regulation 2011/24/EU on Cross-Border Healthcare, has promoted in the context of a specific legislation the development of a system of networking (European Reference Networks) so that a patient with a rare condition may be treated in a local health facility, which is networked with a reference center, in a shared care situation..$^{20}$ In the case of blood disorders, such as thalassemia and SCD, the Eurobloodnet consortium is the responsible European Reference Network ${ }^{21}$ created to put into practice the proposed hub and spoke system of service delivery to rare disease patients.

The various issues faced by migrants are, as yet, only partially met in Europe as is the case with many other rare diseases. There are a variety of factors that influence the access of migrants to optimal care: i) unfamiliarity with the health system and the available services in the host country; ii) language barriers since most migrants do not speak the language and are often of a poor educational background; iii) difficult and delayed diagnosis, both because the laboratories in the vicinity in which the migrants have settled may not be familiar with complexity of diagnosis; iv) they may not have a diagnosis or medical history from their country of origin; v) families are concerned with social issues, such as finding employment and housing as well as facing prejudice and xenophobia, and thus may delay any health concerns.

The purpose of this study is to provide an overview of the current situation in Europe pertaining to thalassemia and SCD, as perceived by the patient/parent community that the Thalassemia International Federation (TIF) represents. This investigation has been undertaken in the context of the 'Thalassemia In Action (THALIA)'

Table 1. The prevalence of thalassemia and sickle cell disease in European countries affected by the migration crises based on data from the International Organization for Migration site.7

\begin{tabular}{|c|c|c|c|c|}
\hline Country & $\begin{array}{c}\text { Carrier rate of } \beta \text {-thalassemia } \\
\text { and SCD in the } \\
\text { indigenous population }\end{array}$ & $\begin{array}{c}\text { No. of accepted migrants } \\
\text { from high prevalence areas } \\
\text { with thalassemia and low } \\
\text { prevalence of SCD }\end{array}$ & $\begin{array}{l}\text { No. of accepted migrants from } \\
\text { high prevalence SCD areas }\end{array}$ & $\begin{array}{l}\text { Estimate of the patient } \\
\text { population } \\
\text { (indigenous and migrant) }\end{array}$ \\
\hline Austria & $0.2 \%$ & 311,000 & 14,000 & $\begin{array}{c}\text { 60-79 BTS* } \\
132 \text { SCD** }\end{array}$ \\
\hline Belgium & $0.28 \%$ & 408,000 & 64,000 & $\begin{array}{c}62 \text { BTS* } \\
358 \text { SCD* }\end{array}$ \\
\hline Denmark & $0.2 \%$ & 171,000 & 16,000 & $\begin{array}{c}83 \text { BTS* } \\
236 \text { SCD* }\end{array}$ \\
\hline France & $0.8 \%$ & $3,993,000$ & 511,000 & $\begin{array}{c}666 \mathrm{BTS}^{8,9} \\
22,000 \mathrm{SCD}^{10}\end{array}$ \\
\hline Germany & $0.2 \%$ & $3,427,000$ & 127,000 & $\begin{array}{l}600-1600 \text { BTS* }^{*} \\
2000 \text { SCD }^{11}\end{array}$ \\
\hline Netherlands & $0.1 \%$ & 748,000 & 71,000 & $\begin{array}{l}350 \text { BTS* } \\
2000 \text { SCD* }\end{array}$ \\
\hline Norway & $0.1 \%$ & 162,000 & 47,000 & $\begin{array}{l}100 \text { BTS* } \\
\text { ? SCD }\end{array}$ \\
\hline Portugal & $1.44 \%$ & 16,000 & 75,000 & $\begin{array}{l}40 \text { BTS* } \\
800 \text { SCD }\end{array}$ \\
\hline *Serbia & $1.2 \%$ & $\begin{array}{c}\text { Transit country - } \\
\text { Migrants not settled }\end{array}$ & $\begin{array}{c}\text { Transit country - } \\
\text { Migrants not settled }\end{array}$ & 3-5 BTS* \\
\hline Spain & $1.6 \%$ & $1,032,000$ & 228,000 & $\begin{array}{l}100 \mathrm{BTS}^{12,13} \\
800 \mathrm{SCD}\end{array}$ \\
\hline Sweden & $0.3 \%$ & 535,000 & 84,000 & $\begin{array}{l}150 \text { BTS* } \\
584 \text { SCD }\end{array}$ \\
\hline Switzerland & $0.4 \%$ & 531,000 & 35,000 & $\begin{array}{l}62 \text { BTS* }^{*} \\
194 \text { SCD }\end{array}$ \\
\hline Italy & $\begin{array}{l}\text { 4.3\% } \beta \text {-thalassemia } \\
\text { 2.1\% SCD }\end{array}$ & $1,621,000$ & 284,000 & $\begin{array}{l}7044 \text { BTS* } \\
2000 \text { SCD }\end{array}$ \\
\hline UK & $0.1 \%$ & $2,652,000$ & $1,005,000$ & $\begin{array}{c}1564 \mathrm{BTS} \\
14,000 \mathrm{SCD}^{14}\end{array}$ \\
\hline Total & - & $15,679,000$ & $2,581,000$ & - \\
\hline
\end{tabular}

SCD, sickle cell disease; BTS, $\beta$-thalassemia syndromes. ${ }^{*}$ Information on the number of patients, where access to an updated registry is not available are derived from information provided by national experts, either during TIF visits or during the TIF European Symposium for Thalassemia and Sickle Cell Disease (December 2020). 
Framework Partnership between the Federation and the European Commission, initiated in 2018, focused on identifying and addressing the unmet needs and challenges of patients living within the EU with a particular emphasis on migrants with thalassemia and SCD in France, Germany and Sweden (as host countries), and Austria and Serbia (as transit countries), known as 'THALIA countries of priority'.

\section{Methodology}

Through the application of a mixed methods approach, information has been obtained by patients/parents and healthcare professionals working in the field of hemoglobin disorders through a variety of vehicles, as described below. The aim being to establish a comprehensive understanding of the situation and unmet needs faced by the thalassemia patient community living in France, Germany and Sweden, Austria and Serbia. Onsite visits were supplemented by a literature search concerning epidemiology and service description.

\section{Onsite delegation visits}

In each visit a delegation was composed of medical specialists and/or patient advocates along with a local TIF member.

During each visit, the TIF delegation met with medical specialists, health author- ities and patient associations (if in existence) and individual patients/parents to map the situation and tailor the support (e.g. education, awareness raising, advocacy, etc.) provided by TIF accordingly. The TIF delegation team, in collaboration with the local medical community and patients' association, observed a situation analysis. The COVID-19 pandemic has necessitated in 2020 the transition to virtual delegation visits.

\section{Thalassemia-specific prevalence database and literature findings}

TIF maintains a thalassemia-specific prevalence database to monitor the geographical distribution of patients throughout the EU and supports the improvement of existing, and the creation of new public health policies and legislations by national health authorities. This is largely based on published literature but also on locally derived information particularly concerning patient numbers. Although many publications offer a significant contribution towards understanding the epidemiology of these disorders, the lack of reliable and comprehensive national registries for thalassemia and haemoglobinopathies at present suggests a gross underestimation of their prevalence in Europe. In addition, knowledge and understanding of the distribution of patients and prevalence of the disease in each country is a huge contributing

\section{. Results}

A total of 20 onsite TIF delegation visits were conducted to the five THALIA countries of priority (France, Germany, Austria, Sweden and Serbia), between January 2018 - March 2020. In addition, 15 virtual meetings took place during 2020 with patients/parents and treating physicians from each of the aforementioned countries. The total number visits/virtual meetings and persons (patients/parents and medical specialists) which the delegation teams interacted per country with are shown in Table 2 .

An overview of the available infrastructure including national policies for screening and access to healthcare services for migrants, diagnostic competencies, treatment centers visited during the THALIA program with expertise in the clinical management of hemoglobin disorders as well as support groups for patients transpired through efforts exerted in the context of this study, as demonstrated in Table 3.

Onsite visits to hospitals, treating centers, laboratories and patient support groups were conducted in each of the delegation visits, in order to engage in discussion with the relevant stakeholders to obtain information about services provided (either at the specific health providing unit or across the country; Table 4) and to map the epidemiological situation in each country (Table 5).

Table 2. TIF Delegation Team interactions with stakeholders in the THALIA countries of priority.

\begin{tabular}{lcccccc} 
& France & Germany & Austria & Sweden & & Serbia \\
No. of visits/virtual meetings & 10 & 9 & 10 & 4 & 3 & 36 \\
No. of patients/parents & 123 & 143 & 140 & 45 & 22 & 57 \\
\hline No. of medical specialists & 158 & 66 & 16 & 12 & 297 \\
\hline
\end{tabular}

Table 3. Available infrastructure for patients in THALIA countries of priority.

\begin{tabular}{|c|c|c|c|c|c|c|}
\hline \multicolumn{2}{|l|}{ Infrastructure } & Austria & France & Germany & Sweden & Serbia \\
\hline \multicolumn{2}{|c|}{ National Screening Policy } & No & No & No & No & No \\
\hline \multicolumn{2}{|l|}{ Diagnostic Laboratories } & Yes & Yes & Yes & Yes & Yes \\
\hline \multicolumn{2}{|c|}{ Treatment Centres Visited } & 2 & 2 & 8 & 2 & 1 \\
\hline \multicolumn{2}{|l|}{$\begin{array}{l}\text { Patient Support Group } \\
\text { (Disease-specific) }\end{array}$} & $\begin{array}{c}\text { No } \\
\text { (Created in } 2019 \\
\text { by TIF initiative) } \\
\end{array}$ & $\begin{array}{c}\text { Yes } \\
\text { (National and } \\
\text { Local coverage) }\end{array}$ & $\begin{array}{c}\text { Yes } \\
\text { (Several with } \\
\text { local coverage) }\end{array}$ & No & None \\
\hline $\begin{array}{l}\text { Access to healthcare } \\
\text { services }\end{array}$ & $\begin{array}{l}\text { Insurance coverage } \\
\text { for registered migrants } \\
\text { Insurance coverage } \\
\text { undocumented migrants }\end{array}$ & $\begin{array}{c}\text { Yes fully } \\
\text { Covered by NGOs }\end{array}$ & $\begin{array}{c}\text { Yes fully } \\
\text { Scheme exists under } \\
\text { State Med Aid }\end{array}$ & $\begin{array}{l}\text { Yes but several providers } \\
\text { with variable coverage } \\
\text { Only for } \\
\text { emergency care }\end{array}$ & $\begin{array}{l}\text { Yes fully } \\
\text { Children fully covered; } \\
\text { adults subsidized }\end{array}$ & $\begin{array}{l}\text { Yes fully } \\
\text { Transient } \\
\text { migrants are } \\
\text { supported }\end{array}$ \\
\hline
\end{tabular}




\section{Other findings and observations}

The dispersal of patients with hemoglobin disorders across the entire host country, as well as the historical settlement of migrants from high prevalence areas, has necessitated the development of centers of expertise in the management of thalassemia and SCD. These centers, are mostly found in urban areas of France and Germany. However, networking with treating physicians and centers in more rural areas appears to be limited. By contrast, in Sweden and Austria services are located in capital cities where hematology departments (pediatric and adult) are providing care for these rare blood disorders but with limited networking. Quality of care was variable in main cities, whilst in rural areas or peripheral towns knowledge on the appropriate clinical management of these disorders is severely limited due to rarity of cases. Patients in Serbia are distinctly even more scarce in comparison to France, Germany, Austria and Sweden, for two reasons: i) migrant patients are sporadic and remain on Serbian soil for a very limited amount of time, transiting to settle in other European countries; and ii) the patients from the indigenous population are very few due to the low prevalence rate.

One striking feature, common to all treating centers visited, is that because of the low numbers of patients, the vast majority of patients transfused in the same center do not know each other and never meet (even though they may be in the next room). This is in stark contrast to the sense of community and belonging experienced by patients in countries where there are significant number of patients, even in Europe (e.g. Cyprus, Italy, Greece, UK). Therefore, patients with thalassemia have reported through interviews feelings of isolation and social marginalization, sometimes to a larger extent than patients with SCD who seem to be generally more abundant. This is further evidenced by the absence of thalassemia-specific patient support groups (Table 3) in Sweden, Austria and Serbia; as well as the existence of small number of such groups in Germany and France. Indeed, in the case of the France and Sweden, thalassemia patients appeared to be supported in a limited fashion by the SCD federation and blood cancer association respectively. The efforts exerted in the context of this study since 2018 has seen a shift towards the defining of functional support groups in Germany and Austria and the further empowerment of the patient community in France and Sweden. Serbia, as a transient country for migrants and with extremely low number of patients with thalassemia, necessitates an ad-hoc support approach for individual patients.

High quality laboratory services enabling the diagnosis of carriers, affected patients, prenatal diagnosis and neonatal screening are available in all the THALIA countries of priority. The rarity of encountering these disorders requires further awareness among laboratory personnel to pursue further investigation of low indices, to differentiate between other causes of anemia (e.g. iron deficiency) and between patients and carriers. The provision of reliable results using validated methods is imperative, notwithstanding the responsibility for their interpretation lies with the clinicians. Routine screening or genetic counselling policies were not in effect in any country under study. The familiarity of primary care physicians with suggestive symptoms or suspicion of carrier/patient status based on ethnic origin, and hence recommendations for appropriate referrals, could not be assessed at this stage.

Universal health coverage allows for the access of all thalassemia and SCD patients (including documented migrants) to basic treatment (i.e. blood transfusion and iron chelation), as well as access to the complex monitoring required in these

Table 4. Summary of Healthcare Services provided to patients with hemoglobin disorders as deduced from TIF Delegation Visits (20182020).

\begin{tabular}{|c|c|c|c|c|c|}
\hline Services & Austria & France & Germany & Sweden & Serbia \\
\hline National registry & No & $\begin{array}{c}\text { Yes } \\
\text { (separate for thalassemia } \\
\text { and SCD) }\end{array}$ & $\begin{array}{c}\text { Yes } \\
\text { (SCD registry is active; } \\
\text { thalassemia registry is } \\
\text { under development) }\end{array}$ & No & No \\
\hline $\begin{array}{l}\text { National guidelines for the } \\
\text { clinical management }\end{array}$ & No & Yes & $\begin{array}{c}\text { Yes } \\
\text { (partial adherence) }\end{array}$ & $\begin{array}{c}\text { Yes } \\
\text { (only for thalassemia) }\end{array}$ & No \\
\hline $\begin{array}{l}\text { Pre-transfusion } \\
\text { Hb (for thalassemia } \\
\text { patients) }\end{array}$ & $\begin{array}{l}\text { Children } 9-10 \mathrm{~g} / \mathrm{dL} \\
\text { Adults } 6-8 \mathrm{~g} / \mathrm{dL}\end{array}$ & $\begin{array}{l}\text { Reference centers: } \\
9-10 \mathrm{~g} / \mathrm{dL} \\
\text { Peripheral centers: } \\
<9 \mathrm{~g} / \mathrm{dL}\end{array}$ & $\begin{array}{l}\text { Reference centers: } \\
9-10 \mathrm{~g} / \mathrm{dL} \\
\text { Peripheral centers: } \\
\text { Variable < } 9 \mathrm{~g} / \mathrm{dL}\end{array}$ & $\begin{array}{c}\text { Reference centers: } \\
9-10 \mathrm{~g} / \mathrm{dL} \\
\text { Peripheral centers: } \\
\text { Variable }<9 \mathrm{~g} / \mathrm{dL}\end{array}$ & $9-10 \mathrm{~g} / \mathrm{dL}$ \\
\hline $\begin{array}{l}\text { MRI availability for iron } \\
\text { overload monitoring }\end{array}$ & $\begin{array}{l}\text { Until } 2019 \text { only } \\
\text { for children }\end{array}$ & $\begin{array}{c}\text { Limited to Reference } \\
\text { Centres }\end{array}$ & $\begin{array}{l}\text { Yes but not systematic } \\
\text { referral in all centers }\end{array}$ & $\begin{array}{c}\text { Limited to } \\
\text { Reference Centres }\end{array}$ & Not available \\
\hline Multidisciplinary care & $\begin{array}{l}\text { For adults: } \\
\text { On referral }\end{array}$ & $\begin{array}{l}\text { Limited to Reference } \\
\text { Centres }\end{array}$ & $\begin{array}{l}\text { Limited to Reference } \\
\text { Centres but not } \\
\text { well established }\end{array}$ & $\begin{array}{l}\text { Limited to Reference } \\
\text { Centres but not } \\
\text { well established }\end{array}$ & On referral \\
\hline Networking & Not official & Not official & Exists but variable & Not official & None \\
\hline Genetic counselling & Not organized & Not organized & $\begin{array}{l}\text { Organized processes } \\
\text { of disease-specific knowl }\end{array}$ & Not organized & Not organized \\
\hline
\end{tabular}

SCD, sickle cell disease; Hb, hemoglobin; MRI, magnetic resonance imaging.

Table 5. Estimated No. of patients in each of the THALIA countries of priority.

\begin{tabular}{lccccc} 
& Austria & France & Germany & Sweden & \\
Thalassemia & $60-79$ & 666 & $600-1600$ & 150 & N/A \\
SCD & 132 & $22-28,000$ & 2000 & 584 & N/A \\
\hline
\end{tabular}

SCD, sickle cell disease. 
chronic disorders. Affordability is an essential requirement for patient outcomes. Undocumented migrants fall below the health systems radar, not being officially eligible for the receipt of care, often reaching emergency departments or health-related NGO's, where they can receive treatment free-of-charge. Neither of which however possessing the necessary expertise in the management of these complex diseases. Thus, it is more likely for such patients to develop medical complications that without timely and appropriate management in an expert multidisciplinary care setting, will quickly result in health deterioration. Moreover, specialized monitoring tests are variably covered by the responsible paying bodies (e.g. insurance). For example, MRI for the measurement of iron overload, an essential monitoring test for the early detection and prevention of iron damage to vital organs with great impact on patient survival $^{22}$ is available in reference centers in Austria, Germany, France and Sweden but not always reimbursed by paying bodies. Furthermore, the absence of the service in the periphery makes the need for patients to visit reference centers, at least annually, imperative.

National guidelines, developed based on TIF's International Guidelines for the Clinical Management of Transfusion Dependent and Non-Transfusion Dependent Thalassemia, adapted to national circumstances, exist in France, Germany and Sweden. Furthermore, a shared language allows Austrian physicians to refer to German published guidelines. Nonetheless there is diverse awareness about the existence of national guidelines by treating physicians across each country. This is evident by consistently lower than recommended pre-transfusion hemoglobin levels in many patients, especially in adult clinics. Moreover, many patients transfused in peripheral centers, present for transfusion when they feel the need (pallor, fatigue) rather than in accordance to protocol. In addition, in some cases, wrong doses of chelating agents were also reported by patients.

Organized multidisciplinary follow up and management of complications is an essential component for the improved survival of patients. ${ }^{18,23,24}$ In view of the lifelong effects on the heart, liver, kidneys, endocrines and other organs, specialists from several disciplines are expected to contribute to the holistic care of patients by providing both early detection and complication management. This of course should be done by specialists who have become familiar with the hemoglobin disorders, and are in communication and complete collab- oration with the hematology team, taking common and agreed upon therapeutic decisions and where possible sharing patient visits and communication. In the centers visited in the course of this study, such organized teams were found in only in two adult centers - one in France and one in Germany, and one pediatric center in Austria. In general, patients are referred to specialists once they have developed a complication, while visiting specialists from an early age and before a 'fait accompli' was found to be rare. Even though the concept of reference centers, as mentioned above is a recognized concept in Europe, actual networking in a shared-care relationship with the periphery where patients may be receiving their routine care, has not been formalized. Despite this, patients have mentioned to the TIF teams that on their initiative they do go to visit a reference center occasionally.

Disease-specific registries, endorsed by the national health authorities were identified in France ${ }^{8}$ and Germany. ${ }^{11}$ More specifically, the French National Registry covers both thalassemia and SCD whereas in Germany the registry is for SCD while for thalassemia it is in the early stages of functioning. The French National Thalassemia Registry constitutes a best-practice example in Europe, demonstrating the value of developing national disease-specific registries as a service planning tool, as it clearly shows the increasing numbers of thalassemia patients living in the country (and therefore increasing requirements of the healthcare system). Indeed a total of 287 individuals were registered in 2008; 479 in 2010; 515 in 2012 and 666 in 2019. ${ }^{9}$ Austria, Sweden and Serbia did not have nationally endorsed disease-specific registries for hemoglobin disorders.

Notably early on in the study it became apparent that health and other services provided for thalassemia overlapped with those provided for SCD, as both disorders are part of the haemoglobinopathy family. Therefore, recommendations and subsequent actions included both disorders, which despite their distinct and different pathophysiology are treated in the same centers, often by the same physicians. In fact, this overlap in services leads patients with both disorders also to face some of the same challenges, as a result not only due to their rarity in the specific countries which are the focus of this study, but also as a consequence of the distinct difficulties faced by migrant communities in general.

\section{Discussion}

Migration has changed the local preva- lence of both inherited and acquired diseases, ${ }^{25}$ and the chronic disorders are a particular challenge. The countries selected for the purposes of the THALIA program were selected as representing the effects of recent migrations and to explore the question whether Europe is ready to meet the medical, social, economic and public health challenges associated with hemoglobin disorders. Acknowledging robust health infrastructure in most of the EU countries, the concept of chronicity with multiple and cumulative organ damage and the need for secondary prevention has not entered the clinical practice of managing these patients who after all are suffering from rare conditions, little known in the host country. However, many other rare congenital red cell disorders are managed by hematologists in Europe, which are met in the indigenous populations that they serve. Is the management of Diamond-Blackfan syndrome, for example, so vastly different from that of beta thalassemia? Could the weaknesses that healthcare systems demonstrate not be due to the sudden increase in cases, but a result of a general weakness in the attention given to the so-called 'benign' as opposed to malignant blood disorders? Could the issue of ethnicity be an additional factor in the provision of expert care?

Europe has long recognized the needs of rare diseases, developing policies and services, such as the creation of registries and the development of European Reference Networks (ERNs). ${ }^{26,27}$ In addition, there are numerous centers of excellence and pioneers in research in many European countries. Experts are aware and are considering improvements and actions in critical areas. ${ }^{28}$ Despite this, haemoglobinopathy patients do not, in many cases, benefit from the expert care that their new place of residence can provide, thus achieving maximal survival and quality of life. Experience from the visits of TIF teams, indicates an uneven availability of expert help. This is less related to the provision of adequate and safe blood transfusion and the availability of essential medications, but to expertise in their appropriate and timely use. As a consequence, low pretransfusion hemoglobin and high iron loads were observed. Likewise worrying was the poor performance in providing timely and coordinated multidisciplinary care. These negative impressions were confirmed by patients who generally felt isolated, with little support from organized support groups. These findings are in line with other rare diseases, which face similar issues in the provision of early diagnosis and optimal care.

Hemoglobin disorders however are dis- 
tinguished from other rare diseases only in that they are more recently imported by migrations. The conclusion then is that they should be provided with all European provisions for rare diseases with the addition of more intense awareness raising and more education of healthcare professionals and the migrant families. In addition, the socioeconomic problems that arise when a family arrives in a new environment, a new culture and a health system that has intricacies to which they must become familiar with, deserves particular attention. Furthermore, the creation and empower- ment of patient groups in these countries in an effort to provide peer-to-peer support, present their own distinct challenges directly related to the heterogenous cultural, linguistic, religious, social, educational backgrounds of the migrant communities in which these disorders are found within the host country. This is a stark difference to the homogenous communities that set up powerful patient groups in EU countries with a high prevalence in the indigenous population (e.g. Cyprus, Greece, Italy).

The onus of providing quality care rests with healthcare authorities as well as the treating physicians, since chronic and rare conditions require organization of services. The requirement is not necessarily to create specialized haemoglobinopathy clinics where few patients exist, but to incorporate them into benign hematology clinics including day transfusion units, separate from patients with malignant conditions receiving chemotherapy for obvious reasons. Moreover, networking, with adequate planning and support, does not seem to be effective as yet, and the referral relationship between the expert and the physician who sees one or two cases, is not yet an estab-

Table 6. Actions taken in the THALIA Work Program (2018-2020) for meeting challenges and unmet needs of hemoglobin disorders. Policy-Makers:

Thalassemia EU Health Record: Continuing to monitor the epidemiology of hemoglobin disorders in Europe, an example of which is the Italian WEBTHAL clinical database. 30

- Advocating for the rights of patients with thalassemia and migrants in the EU through meetings with the EU Health Commission and health authorities of Greece, Cyprus and Italy (2020).

- Connecting with international bodies, national health authorities and foreign relations envoys to highlight the relation of thalassemia in the EU and migration (2018-2020).

- $\quad$ EU Policy Recommendation \& National Charter of Priorities: Comprehensive documents outlining the challenges faced by patients and identifying opportunities for policy changes at the EU and national levels.

Participation in EU Health Program High Level Conference (2019) to inform and raise awareness about THALIA, thalassemia, SCD, migration and the impact on health infrastructure.

\section{Patients \& Families:}

- Thal e-course: an online interactive educational platform providing disease-specific information as well as information on relevant policies and recommendations for advocacy purposed. Available in English, French, German, Greek, Italian, Arabic and Turkish.

- Train-the-Trainers Capacity Building Workshop for Patients' and Patient Associations (Thessaloniki, 2018; Hamburg, 2019; Virtual, 2020)

- THALIA Mobile Application: launched in 2020, aiming to improve self-management.

- Exchange of best practices through twinning programs (Cyprus/France, 2018; Greece/Germany, 2019).

- Educational webinars (4 in total) on disease-specific issues for thalassemia and SCD.

- Creation of TIF's European Patient Advocacy Group for Thalassemia \& Sickle Cell Disease. Total meetings organized: 3.

- Clinical Trials Update: A digest provided to patients/parents every two months on the latest developments regarding clinical trials in the field (2018-2020).

- Support and provision of technical expertise to patient organizations through empowerment (v. France, Germany), establishment (v. Austria) and mobilization (v. Sweden).

- Publication of brochures on Gene Therapy, Bone Marrow Transplantation \& Prevention of Inherited Disorders (2018-2019).

- Thalassemia from A-Z: a comprehensive e-glossary for patients with thalassemia (2019).

- Development of resources for COVID-19 and hemoglobin disorders including information about the effects of SARS-CoV-2 on patients, blood transfusion, Sickle Cell Disease, Vaccines and Therapeutic Drugs, etc. (2020).

\section{Healthcare professionals:}

eThalEd e-course: an online course on the clinical management of thalassemia. Available in English, French and Arabic. e-SCD course: an online course on the clinical management of SCD (2020).

Guidelines for the Clinical Management of Non-Transfusion Dependent Thalassemia. Available in English and French (2018).

Guidelines for the Clinical Management of Transfusion Dependent Thalassemia. Updated 4th edition (In print).

- Short Guide for the Clinical Management of Transfusion Dependent Thalassemia. Distribution across Europe.

High Level Summit for Healthcare Professionals (Thessaloniki, 2019).

- Symposium for Healthcare Professionals in Europe (Virtual, December 2020).

- Renzo Galanello Fellowship. Training of 5 physicians (2018-2020).

- Educational webinars (7 in total) on various aspects of thalassemia clinical management (2020).

- Development of resources for COVID-19 and hemoglobin disorders including a Haemoglobinopathy Patient Pathway (Available in English and Greek) and Risk Classification (2020).

- Raising awareness among EU health professionals through participation in Annual Congress of European Hematology Association (2018-2020), International Society for Blood Transfusion (2018), European Association for the Study of Liver (2019).

\section{General Public:}

- Publication and dissemination of awareness raising posters on Migration and brochures on Prevention of Inherited diseases: -thalassemia.

Articles in press and interviews regarding thalassemia, migration and Europe.

- TIF website: Updating daily with news. Available in English, French, German, Greek, Italian, and Arabic.

- Training of European Solidarity Corps volunteers from Germany, France and Italy about hemoglobin disorders and the migration of populations from high prevalence areas to Europe as refugees, political asylum seekers and economic migrants (2019-2020). 
lished practice in many locations. The beliefs by many hematologists that these blood disorders, due to their benign nature (as opposed to malignant hematological diseases) are simpler in their management, and merely entail the provision of blood and medications, is an unfortunate common perception.

A country that stands out in the European setting is the UK. In this country for many decades populations from the commonwealth countries have been settling and are now in second and third generation. This has led to planning of reference centers and commissioning, especially located in areas where these communities live, networking, quality control of centers with annual reviews, registries, research, national guidelines on all aspects of clinical management, including psychosocial support. Finally, a national prevention program based mainly on antenatal clinic and neonatal screening, prenatal and pre-implantation genetic testing. ${ }^{29}$ This kind of comprehensive planning is expected be followed by all European health services as these conditions become more visible.

The THALIA Work Program (20182020) has enabled, as demonstrated in this study, to identify the location of patients with hemoglobin disorders as well as to further understand the challenges met by both patients and healthcare professionals in the receipt and provision of quality healthcare respectively. In addition to this situation analysis, the THALIA Work Program facilitated the implementation of corrective measures to alleviate the challenges identified through activities listed in Table $6 .{ }^{30}$

\section{Conclusions}

Improving case management and developing a culture to focus on rare and chronic disorders, which are recently appearing in the spectrum of clinical experience of local specialists, is a challenge. The organization of healthcare services for unfamiliar conditions to the authorities, raising awareness to a health burden which is now increasing, requires a resilience in health service management, when concerns over adequacy of budgetary support are paramount. The fact that poor monitoring and treatment now will increase complications and costs over time is not known to many services. Change in some settings takes time, especially where a culture of networking and collaborative care is a necessity. Such networking is possible because centers of expertise do exist in most European countries. The management of hemoglobin disorders shares the same difficulties with other rare conditions in Europe. Additional issues arise because the conditions are recently imported, and the social considerations of immigrant populations. Nonetheless, there is ample international expertise and knowledge to be offered for the appropriate clinical management and care of patients with hemoglobin disorders, that would guarantee an improved quality of life.

\section{References}

1. Piel FB, Patil AP, Howes RE, et al. Global distribution of the sickle cell gene and geographical confirmation of the malaria hypothesis. Nat Commun 2010;1:104.

2. Plato CC, Rucknagel DL, Gershowitz H. Studies on the distribution of glucose-6-phosphate dehydrogenase deficiency, thalassemia, and other genetic traits in the coastal and mountain villages of Cyprus. Am J Hum Genet 1964;16:267-83.

3. Modell B, Darlison M, Birgens H, et al. Epidemiology of hemoglobin disorders in Europe: an overview. Scand J Clin Lab Invest 2007;67:39-69.

4. Aguilar Martinez P, Angastiniotis M, Eleftheriou A, et al. Haemoglobinopathies in Europe: health \& migration policy perspectives. Orphanet J Rare Dis 2014;9:97.

5. Grosse R, Lukacs Z, Cobos PN, et al. The prevalence of sickle cell disease and its implication for newborn screening in Germany (Hamburg Metropolitan Area). Pediatr Blood Cancer 2016;63:168-70.

6. Hunter P. The refugee crisis challenges national health care systems: Countries accepting large numbers of refugees are struggling to meet their health care needs, which range from infectious to chronic diseases to mental illnesses. EMBO Rep 2016;17:492-5.

7. International Organization for Migration (IOM). Migration data Europe. Available from: https://migration.iom.int/europe?type $=$ arrivals

8. Thuret I, Pondarré C, Loundou A, et al. Complications and treatment of patients with $\beta$-thalassemia in France: results of the National Registry. Haematologica 2010;95:724-9.

9. Agouti I, Thuret I, Bernit E, et al. Data from the French registry for beta-thalassemia patients. EHA Learning Center. Badens C 2019;266587.

10. Global Blood Therapeutics. Overview of the sickle cell disease environment in select European countries; October 2020. Available from: https://ir.gbt.com/static-files/29a0775c- ed27-4778-8c10-90dbb9ae1f09

11. Kunz JB, Lobitz S, Grosse R, et al.; German Sickle Cell Disease Registry. Sickle cell disease in Germany: Results from a national registry. Pediatr Blood Cancer 2020;67:e28130.

12. Cela E, Bellón JM, de la Cruz M, et al.; SEHOP-Hemoglobinopathies Study Group (Sociedad Española de Hematología y Oncología Pediátricas). National registry of hemoglobinopathies in Spain (REPHem). Pediatr Blood Cancer 2017;64:26322.

13. Bardón Cancho EJ, García-Morín M, Beléndez C, et al. Update of the Spanish registry of haemoglobinopathies in children and adults. Med Clin (Barc) 2020;155:95-103.

14. National Health Service. NHS Haemoglobinopathy Annual report for 2018-9. Available from: ht t p s ://n hr.mds a s.com/w pcontent/uploads/2019/06/NHR_Annual Report201819.pdf

15. Frontex. Migratory map - Europe. Available from: https://frontex.europa.eu/along-eu-borders/migratory-map/

16. Nelson EC, Dixon-Woods M, Batalden $\mathrm{PB}$, et al. Patient focused registries can improve health, care, and science. BMJ. 2016;354:13319.

17. Taher AT, Weatherall DJ, Cappellini MD. Thalassemia. Lancet 2018;391:155-67.

18. Cappellini MD, Cohen A, Porter J, et al., eds. Guidelines for the management of transfusion dependent thalassemia (TDT) [Internet]. 3rd ed. Nicosia (CY): Thalassemia International Federation; 2014.

19. Farmakis D, Giakoumis A, Angastiniotis M, Eleftheriou A. The changing epidemiology of the ageing thalassemia populations: A position statement of the Thalassemia International Federation. Eur J Haematol 2020;105:16-23.

20. Aymé S, Rodwell C. The European Union Committee of Experts on Rare Diseases: three productive years at the service of the rare disease community. Orphanet J Rare Dis 2014;9:30.

21. EuroBloodNet. Available from: https://eurobloodnet.eu/

22. Modell B, Khan M, Darlison M, et al. Improved survival of thalassemia major in the UK and relation to $\mathrm{T} 2 *$ cardiovascular magnetic resonance. J Cardiovasc Magn Reson 2008;10:42.

23. Noronha SA, Sadreameli SC, Strouse JJ. Management of sickle cell disease in children. South Med J 2016;109:495- 


\section{Article}

502.

24. Powell RE, Lovett PB, Crawford A, et al. A multidisciplinary approach to impact acute care utilization in sickle cell disease. Am J Med Qual 2018;33:127-31.

25. European Centre for Disease Prevention and Control (ECDC). Assessing the burden of key infectious diseases affecting migrant populations in the EU/EEA. Stockholm: ECDC; 2014.

26. Baldovino S, Moliner AM, Taruscio D, et al. Rare diseases in Europe: from a wide to a local perspective. Isr Med Assoc J 2016;18:359-63.

27. Moliner AM, Waligora J. The European Union Policy in the field of rare diseases. Adv Exp Med Biol 2017;1031:561-87.

28. Iolascon A, De Franceschi L, Muckenthaler M, et al. EHA research roadmap on hemoglobinopathies and thalassemia: an update. Hemasphere 2019;3:e208.
29. Weil LG, Charlton MR, Coppinger C, et al. Sickle cell disease and thalassemia antenatal screening programme in England over 10 years: a review from 2007/2008 to 2016/2017. J Clin Pathol 2020;73:183-90.

30. Longo F, Corrieri $\mathrm{P}$, Origa $\mathrm{R}$, et al. Changing patterns of thalassemia in Italy: a WebThal perspective. Blood Transfus 2020. [Epup ahead of print]. 